\title{
Pergeseran Bahasa Baku: Ragam Bahasa Elitis dalam Akun Instagram Humor Recehku
}

\author{
Standard Language Shift: Variety of Elite Languages in the Instagram \\ Account of Humor Recehku
}

\author{
Wiwik Ariesta ${ }^{1, *}$, Atika Lisamawati Nur Qoyyimah' ${ }^{2}$, dan Markhamah ${ }^{3}$ \\ ${ }^{1,2,3}$ Magister Pendidikan Bahasa Indonesia, Universitas Muhammadiyah Surakarta \\ ${ }^{1}$ Corresponding email: wiwik27agustus@gmail.com \\ ${ }^{2}$ Email: atikalisamawatinurqoyyimah@gmail.com \\ ${ }^{3}$ Email: mar274@ums.ac.id
}

Received: 12 December 2020 Accepted: 5 July 2021 Published: 1 August 2021

\begin{abstract}
The purpose of this study is to describe elitist language on the Humor Recehku Instagram account, namely (1) nonstandard word forms; (2) abbreviated forms that cause non-standard; and (3) word forms from foreign languages. The method used in this research is the descriptive method. The data collection technique was done by observing and taking notes. Data analysis used Miles and Huberman qualitative analysis, namely data reduction, data presentation and drawing conclusions and levers. This research leads to the content analysis "content analysis". The data in this study are in the form of words, phrases, and sentences that experience language shifts in an elitist form. The results of this study indicate that there is a language shift in the case of using elitist language in the Humor Recehku Instagram account. First, non-standard word forms include non-standard words without a play (emang, gini, telfon, sampe, ngerasa dan sebagainya); non-standard words with a pun (Oktrouble dan gw); and non-standard words weakening phonemes (males, denger, bener-bener, ye, cakep, anjeng, kecapean, dan temen). Second, abbreviations that cause non-standard abbreviated standard words (sm, org, krn, dan trs); and abbreviated non-standard words (not and yesterday2). Third, foreign language words are divided into (typing, excuse, mood and so on); phrase (self-reminder, close friend IG); and sentences (is the best kind of sleep, oh well honey, you keep your small circle, and friend with many but trust any).
\end{abstract}

Keywords: language shift, standard language, elitist language

\begin{abstract}
Abstrak: Tujuan penelitian ini memaparkan bahasa elitis pada akun instagram Humor Recehku, yaitu (1) bentuk kata tidak baku (2) bentuk singkatan yang menyebabkan tidak baku; dan (3) bentuk kata dari bahasa asing. Metode yang digunakan dalam penelitian ini, yaitu metode deskriptif. Teknik pengumpulan data dilakukan dengan teknik simak dan catat. Analisis data menggunakan analisis kualitatif Miles dan Huberman, yaitu reduksi data, penyajian data serta penarikan kesimpulan dan verifikasi. Penelitian ini mengarah pada analisis isi "content analysis". Data dalam penelitian ini berupa kata, frasa, maupun kalimat yang mengalami pergeseran bahasa dalam bentuk elitis. Hasil penelitian ini menunjukkan bahwa terdapat pergeseran bahasa pada kasus penggunaan ragam bahasa elitis dalam akun instagram Humor Recehku. Pertama, bentuk kata tidak baku meliputi kata tidak baku tanpa plesetan (emang, gini, telfon, sampe, ngerasa dan sebagainya); kata tidak baku dengan plesetan (Oktrouble dan $g w$ ); dan kata tidak baku pelemahan fonem (males, denger, bener-bener, ye, cakep, anjeng, kecapean, dan temen). Kedua, bentuk singkatan yang menyebabkan tidak baku terdiri atas kata baku yang disingkat (sm, org, $\mathrm{krn}$, dan trs) dan kata tidak baku disingkat (gak dan kemaren2). Ketiga, kata bahasa asing dibagi atas kata (typing, excuse, mood dan sebagainya); frasa (self reminder, close frind $I G$ ); dan kalimat (is the best kind of sleep, oh well honey, you keep your small circle, dan friend with many but trust any).
\end{abstract}

Kata kunci: pergeseran bahasa, bahasa baku, bahasa elitis

To cite this article:

Ariesta, W., Qoyyimah, A. L. N., \& Markhamah. (2021). Pergeseran Bahasa Baku: Ragam Bahasa Elitis dalam Akun Instagram Humor Recehku. Diglosia: Jurnal Kajian Bahasa, Sastra, dan Pengajarannya, 4(3), $259-274$. https://doi.org/10.30872/diglosia.v4i3.159 


\section{A. PENDAHULUAN}

Unsur terpenting dalam berkomunikasi ialah bahasa. Menilik perkembangannya, pemakaian bahasa tidak lagi dapat dikatakan baik dan benar. Di dalam kehidupan sehari-hari bahasa mulai mengalami pergeseran. Penggunaan bahasa sesuai kaidah yang awalnya mempermudah untuk menyampaikan pesan atau informasi dengan tujuan komunikasi berjalan dengan efektif, kini bergeser atau berubah menjadi bahasa anak remaja yang tidak sesuai dengan kaidah-kaidah atau standar baku bahasa Indonesia. Penggunaan bahasa Indonesia yang baik dan benar sangatlah penting untuk diketahui oleh remaja. Hal ini supaya bahasa Indonesia yang merupakan bahasa nasional, bahasa persatuan, dan bahasa pengantar dalam dunia pendidikan bisa tetap ada dan tidak kalah eksistensinya daripada bahasa gaul (Gustiasari, 2018, pp. 433-434).

Kesalahan umum pemakaian bahasa Indonesia dalam masyarakat merupakan suatu gejala yang wajar. Kesalahan umum berbahasa Indonesia yang timbul dalam masyarakat, antara lain, karena bahasa Indonesia sedang berkembang. Penggunaan bahasa Indonesia sedang menuju ke penggunaan bahasa yang standar. Di satu pihak para pakar bahasa menyarankan pemakaian bahasa yang sesuai dengan kaidah, tetapi di pihak lain masyarakat masih terbiasa berbahasa dengan mengabaikan kaidah. Meskipun demikian, tidak berarti kesalahan umum itu dibiarkan berlarutlarut. Untuk mengetahui kesalahan tersebut, para pemakai bahasa harus meningkatkan keterampilannya dalam memperagakan bahasa Indonesia sesuai dengan aturan atau kaidah yang berlaku.

Ariyanti $(2019$, p. 44) menyatakan bahwa ragam bahasa adalah variasi dalam sebuah bahasa menurut pemakaian yang berbeda-beda. Jamilah (2017, p. 42) memaparkan ada berbagai faktor yang mempengaruhi penggunaan bahasa, misalnya siapa pembicaranya, pendengar yang dihadapi, kondisi, situasi, ruang dan waktu. Salah satu fenomena bahasa ialah penggunaan bahasa elitis yang mewabah di masyarakat dan menyebabkan tidak sedikit orang meninggalkan penggunaan bahasa baku.

Bahasa baku atau bahasa standar adalah bahasa yang mempunyai nilai komunikatif yang tinggi, yang digunakan dalam kepentingan nasional, dalam situasi resmi atau dalam lingkungan resmi dan pergaulan sopan yang terikat oleh tulisan, ejaan baku, istilah/kosa kata baku tata bahasa baku, serta lafal bakum Husain dan Aripin (dalam Supriadin, 2016, p. 152). Untuk itu, dapat dikatakan dengan menggunakan bahasa Indonesia yang baik dan benar, kita telah menjunjung tinggi bahasa persatuan seperti apa yang telah diikrarkan dalam Sumpah Pemuda 28 Oktober 1928. Identitas atau jati diri seseorang akan terbentuk melalui interaksi dengan bahasa dan budaya.

Perkembangan sebuah bahasa dapat berwujud perubahan atau pergeseran. Adanya pergeseran bahasa yang disebabkan oleh adanya faktor kemultibahasaan atau kedwibahasaan yang berkembang di masyarakat. kedwibahasaan (bilingualisme) pada umumnya digunakan berkaitan dengan kemampuan serta kebiasaan menggunakan dua bahasa atau multilingualism (Nababan dalam Bhakti, 2020, p. 29). Paparan tersebut diperkuat dengan pendapat Permatasari et al. (2019, p. 105) bahwasannya kemampuan dwibahasa merupakan salah satu penyebab seseorang salah dalam dalam berbahasa. Selain itu, faktor utama yang yang dapat mempengaruhi pergeseran bahasa adalah sikap penutur terhadap bahasa daerahnya sendiri (Djamareng \& Jufriadi, 2016, p. 86). 
Fenomena pergeseran maupun pemertahanan bahasa terjadi karena adanya kontak antar bahasa dalam suatu masyarakat. Penggeseran bahasa dapat terjadi baik secara lisan maupun tulis. Secara lisan terlihat ketika seseorang sedang berkomunikasi atau terlibat dalam percapakan, sedangkan secara tertulis dapat ditemukan dalam kata-kata atau quotes, seperti dalam humor.

Menurut Gustiasari (2018, p. 23) humor merupakan kemampuan mental dalam menemukan, mengekspresikan, atau mengapresiasikan sesuatu yang lucu atau sesuatu yang benar-benar tidak lazim. Senada dengan pendapat tersebut, Setiyanto (2018, pp. 101-102) menyatakan bahwa humor ialah rangsangan yang menyebabkan seseorang tertawa atau tersenyum dalam kebahagiaan. Untuk itu, dapat disimpulkan bahwa humor ialah salah satu sarana yang dapat digunakan untuk menyegarkan pikiran setelah melakukan berbagai aktivitas atau sebagai hiburan untuk menghilangkan penat.

Akun instagram Humor Recehku salah satunya. Instagram menjadi media sosial dengan peningkatan jumlah pengguna aktif terbesar dalam 4 tahun terakhir. Jumlah pengguna aktif Instagram melonjak 23 persen dari 130 juta pengguna pada Juni 2013 menjadi 150 juta per bulan pada kuartal keempat tahun lalu. Instagram adalah sebuah aplikasi berbagi foto yang memungkinkan pengguna mengambil foto, menerapkan filter digital, dan membagikannya ke berbagai layanan jejaring sosial, termasuk milik Instagram sendiri (Diniati \& Saputro, 2017, p. 61).

Media tersebut digunakan sebagai hiburan. Humor terbagi menjadi dua macam, yaitu humor verbal dan nonverbal. Humor verbal adalah humor yang dipresentasikan dengan bahasa, misalnya berupa tulisan atau ujaran. Humor nonverbal dengan gerak-gerik atau gambar, misalnya dalam pantonim atau karikatur Rustono (dalam Yuwana, 2019, p. 2). Adapun, ragam humor menurut Gustiasari (2018, p. 233) terdiri atas humor positif dan humor negatif. Humor positif ialah humor yang dapat membangkitkan sesuatu yang baik bagi pendengarnya. Adapun, humor negatif adalah humor yang berisi sesuatu yang tidak baik yang berbau SARA, porno, hinaan dan celaan maupun sesuatu yang tidak baik lainnya.

Seperti namanya akun Humor Recehku tersebut menyajikan kata-kata atau kalimat yang menggelitik pembaca. Terlepas dari itu, banyak ditemukan penggunaan kata, frasa, maupun kalimat tidak baku yang merupakan bentuk pergeseran bahasa. Pergeseran tersebut muncul dari adanya penggunaan kata yang bersifat elitis. Permulaan ragam bahasa elitis terjadi akibat gejala perkembangan bahasa Indonesia ke arah perkembangan bahasa tinggi dan bahasa rendah yang dipakai untuk berbicara dengan pihak yang dianggap lebih tinggi dan lebih rendah atau dipakai secara campuran dalam percakapan dengan orang yang dianggap sederajat (Soedjatmiko, 1984, p. 149). Misalnya, dialek Jakarta menjadi dominan dalam pemakaian bahasa Indonesia dewasa ini. Sebagaimana telah digambarkan, pemakaian dialek itu terjadi oleh alasan-alasan yang bersangkut-paut dengan gengsi soial. Dialek Jakarta dianggap memiliki elitisme tertentu di antara dialek bahasa Indonesia lainnya dalam pergaulan masyarakat (Umar, 2007, p. 96).

Pilihan istilah elitis hanya dapat diakses dan dipahami masyarakat kelas menengah atas. Penggunaan bahasa langit dan rumit tersebut hanya menyasar kalangan tertentu. Namun kini, penggunaan bahasa elitis berwujud kata, frasa atau kalimat lebih banyak digunakan masyarakat. Penggunaannya menjadikan orang cenderung dinilai lebih lebih tinggi atau unggul daripada yang lain. Inilah sebabnya 
bahasa yang baik dan benar sesuai tata bahasa baku bahasa Indonesia seringkali ditinggalkan dan terabaikan.

Ragam bahasa baku, jika semakin banyak pemangku kepentingan bahasa yang meninggalkannya, akan semakin elitis. Dahulunya penggunaan bahasa elitis ini mencerminkan tingkatan atau kedudukan seseorang. Akan tetapi, tidak lagi bersifat elitisnya bahasa asing di zaman modern ini, karena semakin banyak orang menggunakan bahasa asing dalam berbagai kesempatan. Pembentukan kata baru dapat dilakukan dengan dua cara, yaitu mengubah kata yang sudah ada dan menciptakan kata baru atau inovasi.

Pembentukan kata yang paling lazim, yakni mengubah kata yang ada menjadi bentuk kata baru (Zaim, 2015, p. 175). Salah satu dari bentuk pergeseran bahasa ialah munculnya kata-kata yang bersifat elitis. Elitis di sini muncul karena dianggap lebih bergengsi. Semakin berkembangnya bahasa membuat generasi muda, khususnya para remaja, menggabungkan kata yang bersifat elitis dengan bahasa yang digunakan sehari-hari sehingga terjadi proses penggeseran bahasa baku. Penggeseran tersebut misalnya, percampuran antara bahasa baku bahasa Indonesia dengan bahasa Inggris, maupun perpaduan akronim "bahasa gaul/ bahasa prokem dan atau bahasa alay" dengan bahasa baku.

Oktavia (2019) meneliti bahasa Indoglish. Hasil penelitian ini menunjukkan adanya wujud Indoglish ditentukan beberapa faktor, meliputi faktor usia, kebahasaan, kesejarahan, pengaruh bahasa asing dan sebagainya. Gunawan (2013) meneliti mengenai penggunaan bahasa gaul. Hasil penelitian menunjukkan bahwa penggunaan bahasa gaul mempengaruhi pemakaian ragam tulis bahasa Indonesi, terlihat dari penggunaan kata sandang bahasa daerah, tanda baca khusus dan penggunaan sistem morfologi tertentu. Penelitian sejenis juga dilakukan Supriadin (2016) yang meneliti kosakata bahasa baku. Hasil penelitian ini memaparkan penyebab bahwa bahasa Indonesia tidak baku karena adanya tukar-menukar huruf dalam kata, pelesapan huruf dalam kata, dan penambahan huruf pada kata.

Penelitian Gunawan (2013) penggunaan bahasa gaul itu telah mempengaruhi pemakaian ragam tulis bahasa Indonesia mereka. Pengaruh itu dapat dilihat dari penggunaan kata sandang bahasa daerah, tanda baca khusus dan penggunaan sistem morfologi tertentu. Penelitian Zaim (2015) menunjukkan bahwa terjadi pergeseran pembentukan kata pada akronim, blending, dan kliping. Pergeseran terjadi pada penyerapan akronim, blending, dan kliping yang berasal dari bahasa asing. Penelitian Bhakti (2020) hasil penelitian Pergeseran bahasa terjadi karena adanya kontak antar bahasa, suatu bahasa dapat menggeser bahasa lain.

Selanjutnya, penelitian terdahulu yang setopik, juga dilakukan oleh Tutik et al. (2020), Yuniar et al. (2020), Permatasari et al. (2019), Qory'ah et al. (2019), Istiqomah et al. (2018), Putri (2018), Sutrisna (2017), Hendrastuti (2015), Raihany (2015), Oktaviani (2014), Rahardi (2014), Sari and Wedasuwari (2014), dan Hilaliyah (2010). Hasil penelitian yang paling dominan dari beberapa penelitian terdahulu yang ditemukan dalam penggeseran bahasa ialah bentuk kesalahan berbahasa dari segi kata, meliputi kesalahan penulisan kata baku, huruf miring, huruf kapital maupun penulisan kata depan. Kesalahan bahasa prokem pun dapat ditinjau dari segi kebahasaan, salah satunya kosakata yang digunakan. Penggunaan bahasa gaul ini harus disesuaikan dengan tempat, situasi, dan siapa lawan bicara. Fenomena Indoglish juga terjadi pada unggahan tulisan di media sosial. Pergeseran-pergeseran tersebut merupakan wujud ragam elitis. Adapun, ragam elitis yang ditemukan dalam 
penelitian ini, di antaranya kata tidak baku bentuk elitis, singkatan yang menyebabkan tidak baku bentuk elitis maupun kata bahasa asing bentuk elitis.

Variasi dan fungsi ragam bahasa ada kalanya digunakan sebagai bagian dari strategi komunikasi pemasaran. Tak dapat dipungkiri, bahwasannya masyarakat khususnya para remaja lebih menyukai menggunakan dua bahasa secara seimbang. Sejauh diikuti oleh kesadaran konteks dan tetap menjunjung tinggi bahasa pemersatu, bahasa Indonesia sebagai tidak akan mengalami pergeseran bahasa yang kemudian menyebabkan kepunahan. Adapun tujuan dalam penelitian ini, memaparkan bahasa elitis pada akun instagram Humor Recehku, yaitu (1) bentuk kata tidak baku; (2) singkatan yang menyebabkan tidak baku; dan (3) kata dari bahasa asing.

\section{B. METODE}

Metode yang digunakan dalam penelitian ini adalah deskriptif kualitatif Metode deskriptif kualitatif digunakan untuk memaparkan pergeseran kata bahasa baku ragam bahasa elitis dalam akun instagram Humor Recehku. Bentuk penelitian ini menafsirkan data yang disajikan dalam bentuk deskripsi kata-kata (Sugiyono, 2014, p. 34). Peneliti dalam penelitian kualitatif ini akan menyimak, memahami, menata, mengklasifikan atau mengkategorikan, menghubungkan antar kategori, dan menginterpretasikan data berdasarkan konteksnya. Data penelitian ini, yaitu sejumlah 34 data yang terdiri atas bentuk kata tidak baku, bentuk singkatan serta kata, frasa dan kalimat dari bahasa asing yang diperoleh dari bulan Oktober sampai dengan November 2020.

Sumber data penelitian ini adalah hasil tangkapan layar berupa tulisan yang diambil dari laman instagram Humor Recehku. Pengumpulan data menggunakan metode simak dan catat. Simak dilakukan dengan membaca dan mencermati bentuk pergeseran bahasa baku ragam bahasa elitis yang digunakan, baik kata, frasa, dan kalimat yang dituliskan atau diposting dalam akun instagram Humor Recehku. Selanjutnya, data yang sudah disimak dicatat berdasarkan klasifikasi yang telah dibuat. Penelitian ini mengarah pada analisis isi "content analysis" yang digunakan untuk mencerna bentuk, makna, fungsi perilaku sosial di dalam suatu konteks dalam dokumen yang besar termasuk di dalamnya ada pengkodean dan pengkategorian (Grbich, 2007). Analisis data dalam penelitian ini menggunakan analisis kualitatif Miles dan Huberman, yaitu reduksi data, penyajian data serta penarikan kesimpulan dan verifikasi. Pertama, reduksi data dengan mengelompokkan data ragam bahasa elitis dalam akun instagram Humor Recehku. Kedua, penyajian data dengan menggolongkan data bentuk pergeseran bahasa. Ketiga, penarikan kesimpulan dan verifikasi dengan menyisihkan data yang serupa namun tak sama (bentuk kata, frasa, maupun kalimat yang ditemukan).

\section{PEMBAHASAN}

Hasil penelitian ini memaparkan bentuk-bentuk pergeseran bahasa baku terkait kasus penggunaan ragam bahasa elitis dalam akun instagram Humor Recehku. Berdasarkan analisis data, ragam bahasa elitis yang ditemukan, meliputi kata tidak baku bentuk elitis, singkatan yang menyebabkan tidak baku bentuk elitis dan kata bahasa asing bentuk elitis. 


\section{Kata Tidak Baku Bentuk Elitis \\ a. Kata Tidak Baku tanpa Plesetan}

(1) males banget denger excuse "aku emang orangnya gini" padahal bisa jadi lebih baik. kamu bukan bonsai, grow up). (12/11/20)

Kata dalam data (1) di atas merupakan kata baku yang ditulis menjadi kata tidak baku tanpa plesetan. Kata dalam data tersebut, yaitu kata emang dan gini. Katakata tersebut akan terlihat baik, jika ditulis dengan memperhatikan kaidah kebahasaan. Kata emang seharusnya "memang", kata gini seharusnya "begini". Pergeseran kata baku tanpa plesetan tersebut sebagai bentuk elitis bagi pengguna media sosial karena penggunaan kata yang sering digunakan seharusnya baku ditulis menjadi kata tidak baku tanpa plesetan.

(2) "Mau aku telfon?"

Kalimat sederhana, tapi bisa bikin mood jadi lebih bagus aja gitu. $(12 / 11 / 20)$

Kata baku ditulis menjadi tidak baku tanpa plesetan pada kata telfon, jika ditulis dengan memperhatikan kaidah kebahasaan "telepon". Pergeseran kata baku tanpa plesetan tersebut sebagai bentuk elitis karena penggunaan telfon lebih sering digunakan masyarakat dalam ragam tulis daripada telepon sebagai bentuk baku.

(3) Banyak yang bilang cewek itu egois, padahal dia sering mengalah bahkan sampe menangis. $(22 / 09 / 20)$

Pergeseran kata baku pada kasus bahasa elitis ini terlihat pada pilihan kata yang digunakan dalam kalimat tersebut, yaitu kata sampe. Kata sampe merupakan kata tidak baku plesetan yang seringkali dipakai para remaja gaul zaman sekarang. Kata sampe seharusnya ditulis "sampai" diakhiri dengan fonem /i/ bukan fonem /e/.

(4) "Sudah berjuang, sudah ngerasa dekat .. eh sekalinya gak masuk close friend IG". (22/09/20)

Bentuk kata "ngerasa" merupakan ragam variasi bahasa elitis dari kata tidak baku tanpa plesetan. Penggunaan prefiks nge- dari kata ngerasa merupakan bentuk tidak baku tanpa plesetan, pembetulan dalam kalimat diatas seharusnya, yaitu "merasa". Pergeseran bahasa elitis pada kata ngerasa sebagai bentuk berstatus di media sosial instagram dengan menggunakan bahasa Indonesia yang tidak baik dan benar. Pengguna akun sosial media dalam ragam tulis pada kata ngerasa tidak baku tanpa plesetan digunakan dalam kehidupan sehari-hari menggunakan bahasa Indonesia yang tidak standar atau tidak sesuai aturan KBBI.

(5) Berusaha ngelupain semuanya tapi belom bisa juga, masi aja lemah. $(25 / 09 / 20)$

Bentuk kata ngelupain dan belom merupakan ragam variasi bahasa elitis dari kata tidak baku tanpa plesetan. Penggunaan prefiks nge- dari kata ngelupain 
merupakan bentuk tidak baku tanpa plesetan, pembetulan dalam kalimat diatas seharusnya, yaitu menggunakan kata "melupakan". Kata yang awalnya merupakan kata baku "masih" dalam kalimat ini mengalami pergeseran menjadi masi. Penghilangan fonem $/ \mathrm{h} /$ menyebabkan kata ini disebut sebagai bentuk tidak baku tanpa plesetan, seharusnya penambahan fonem /h/ menjadi kata "masih" memiliki makna sedang dalam keadaan menurut KBBI.

(6) Kadang, jalan terbaik adalah ngilang, bukan ngulang. (14/10/20)

Ngilang merupakan ragam variasi bahasa elitis dari kata tidak baku tanpa plesetan. Penggunaan prefiks ng- dari kata ngilang merupakan bentuk tidak baku, pembetulan dalam kalimat di atas seharusnya, yaitu menggunakan kata "menghilang". Sedangkan kata ngulang mengalami pergeseran bahasa elitis pada prefiks ng- dari bentuk tidak baku ngulang, pembetulan kalimat di atas seharusnya, yaitu menggunakan kata "menghilang". Pergeseran bahasa elitis kedua kata tersebut ditemukan dalam ragam tulis di media sosial, kosakata tidak baku ngilang dan ngulang dalam penulisan bahasa media sosial, karena pengguna tidak memperhatikan penggunaan kata dalam bahasa keseharian.

(7) ketiduran karna kecapean is the best kind of sleep. (19/09/2020)

Karna merupakan ragam variasi bahasa elitis dari kata tidak baku tanpa plesetan. Pergeseran kata karna dalam bentuk baku, yaitu "karena". Penggunaan karna merupakan bentuk penulisan yang tidak baku dalam KBBI, sebab ada penghilangan fonem /e/ pada kata "karena". Masyarakat pengguna sosial media lebih banyak cenderung menggunakan ragam bentuk tulis tidak baku tanpa plesetan sebagai bentuk bahasa tulis sosial media yang santai dan tidak baku jika digunakan dalam bahasa resmi. Pergeseran bahasa elitis tersebut tersebut sering digunakan dalam pergaulan sehari-hari menggunakan kata karna daripada bentuk baku "karena".

(8) Filter Instagram nih nggak malsuin kecantikan mu, itu Cuma memberi tahumu betapa cantiknya dirimu. $(23 / 09 / 20)$

Malsuin merupakan ragam variasi bahasa elitis dari kata tidak baku tanpa plesetan. Pergeseran kata malsuin tidak menggunakan kata yang baik dan benar sesuai KBBI. Pembetulan dari bahasa tidak baku malsuin seharusnya dalam kalimat di atas menggunakan kata "memalsu" sebagai bentuk baku yang berarti membuat sesuatu yang palsu. Pergeseran kata tidak baku tersebut sering digunakan oleh kalangan masyarakat dalam ragam tulis kurang memperhatikan penulisan yang sesuai KBBI. Pengguna media sosial beranggapan bahwa bahasa di media sosial merupakan bahasa yang tidak resmi, oleh karena itu masyarakat bebas mengutarakan ragam tulis di media sosial.

(9) bakal gw ingat muka temen yang nemenin gw pas lagi susah. (28/09/20)

Nemenin merupakan ragam variasi bahasa elitis dari kata tidak baku tanpa plesetan. Pergeseran kata nemenin tidak menggunakan kata yang baik dan benar 
sesuai KBBI. Pembetulan dari bahasa tidak baku nemenin seharusnya dalam kalimat di atas menggunakan kata "menemani" sebagai bentuk baku. Pergeseran kata tidak baku tanpa plesetan tersebut sudah tidak jarang terlihat, karena pengguna akun media sosial merasa lebih tepat menggunakan kata nemenin daripada "menemani".

(10) Kenapa ya sebagaian cewe lebih suka cowo yang gasuka ke dia. $(29 / 09 / 20)$

Kata cowo dan cewe merupakan ragam variasi bahasa elitis dari kata tidak baku tanpa plesetan. Pergeseran kata cowo dan cewe tidak menggunakan kata yang baik dan benar sesuai KBBI. Pembetulan dari kata tidak baku tanpa plesetan menjadi bentuk baku "cowok" dan "cewek". Kata cowo dan cewe seringkali digunakan untuk menyebut "laki-laki dan perempuan yang masih muda". Pergeseran bentuk elitis dalam penggunaan bentuk tulis dalam media sosial lebih sering menggunakan kata dengan penghilangan fonem $/ \mathrm{k} /$.

\section{b. Kata Tidak Baku dengan Plesetan}

(11) Dan pada akhirnya Oktober bener-bener jadi Oktrouble. $(11 / 10 / 20)$

Oktrouble dikatakan elitis karena menggabungkan kata bahasa Indonesia dengan bahasa Inggris, yakni kata Oktober dan trouble. Kata trouble memiliki arti masalah, sedangkan Oktober adalah bulan. Untuk itu, Oktrouble adalah bulan Oktober yang penuh dengan trouble (masalah) dan konflik. Kata gaul ini biasanya hanya dipahami sebaagian kecil orang, khusunya oleh anak Twitter.

(12) Bakal $g w$ ingat muka temen yang nemenin $g w$ pas lagi susah. $(28 / 09 / 20)$

Kata $g w$ dalam data di atas merupakan padanan dari kata gue, yang berarti "aku atau saya". Pelafalan tersebut lebih sering digunakan sebagai bahasa percakapan sehari-hari para remaja ibu kota. Kata $g w$ merupakan bentuk elitis kata tidak baku dengan plesetan yang digunakan untuk menyatakan ataupun menyebut diri sendiri. Disebut demikian, karena penggunaan kata $g w$ tidak selalu digunakan di seluruh daerah/ kota. Kata $g w$ lekat dan melekat pada kota metropolitan. Penggeseran kata tersebut sering dijumpai dan digunakan dalam bahasa tulis bahasa Indonesia, walaupun tidak sesuai dengan kaidah kebahasaan bahasa baku.

\section{c. Kata Tidak Baku Pelemahan Fonem}

(13) males banget denger excuse "aku emang orangnya gini" padahal bisa jadi lebih baik. kamu bukan bonsai, grow up. $(12 / 11 / 20)$

Kata males mengalami pelemahan fonem /e/, seharusnya bentuk tulisan tersebut "malas" menggunakan fonem /a/. Bentuk kata tidak baku denger pelemahan fonem /e/, seharusnya "dengar" menggunakan fonem /a/. Kata tidak baku pelemahan fonem dalam kalimat tersebut sebagai bentuk elitis karena berhubungan dengan masyarakat yang lebih sering mengalami pergeseran bentuk baku menjadi kata tidak baku pelemahan fonem. 
(14) Dan pada akhirnya Oktober bener-bener jadi Oktrouble. $(11 / 10 / 20)$

Kata ulang bener-bener mengalami pelemahan fonem /e/, seharusnya ditulis "benar-benar" menggunakan fonem /a/. pengunaan elitis sebuah kalimat tergantung pemakai bahasa. Di sini penulis tidak memperhatikan kaidah bahasa Indonesia secara benar, terlihat dari tidak bakunya kata yang digunakan mengalami pelemahan fonem.

(15) ternyata gue cakep juga ye trs kemaren2 insecure buat apaan anjeng. $(28 / 09 / 20)$

Pergeseran bahasa elitis pada kata ye sebagai bentuk tidak baku pelemahan fonem /e/, seharusnya pembetulan dalam bentuk baku, yaitu "ya". Pelemahan fonem /e/ kata ye tersebut merupakan bentuk tidak baku mengalami pelemahan fonem dan tidak memiliki arti, bentuk tersebut hanya menjadi penggeseran bahasa baku "ya" menjadi ye. Bentuk penggeseran ye tidak terdapat dalam KBBI dan tidak memiliki makna.

Cakep merupakan bentuk bahasa elitis bentuk kata tidak baku dengan pelemahan fonem /e/. Pergeseran kata bentuk elitis pada kata cakep, yaitu "cakap" yang berarti "bagus rupanya; cantik; rupawan". Di dalam KBBI cakep dan cakap memiliki arti yang berbeda. Cakep berarti dapat terangkul hingga kedua ujung tangannya bertemu.

Pergeseran bahasa elitis pada kata anjeng sebagai bentuk tidak baku tanpa plesetan, pembetulan dalam bentuk baku, yaitu "anjing". Kata anjing dalam KBBI berarti binatang yang menyusui yang bisa diperlihara untuk menjaga rumah, berburu, dan sebagainya. Pergeseran bahasa elitis pada kata anjeng dalam penggunaan media sosial bagi kalangan anak remaja atau dewasa sebagai bentuk kemarahan, merendehakan martabat seseorang, dan penggunaan pujian yang tergantung pada konteks ragam tulis yang diutarakan oleh kalangan individu dalam penggunaan media sosial.

(16) ketiduran karna kecapean is the best kind of sleep. (19/09/2020)

Pergeseran kata kecapean dalam bentuk baku, yaitu "kecapaian" dalam KBBI yang berarti merasa sangat capai (lelah, letih); kelelahan; keletihan. Penggunaan kata kecapean merupakan bentuk penulisan yang tidak baku dalam KBBI, sebab ada pelemahan fonem antara "a dengan e" dan penghilangan fonem /i/ dalam kata baku "kecapaian". Masyarakat pengguna sosial media lebih banyak cenderung menggunakan bentuk bahasa elitis yang tidak baku dalam penggantian fonem dan penghilangan fonem pada bentuk "kecapaian" disebabkan oleh masyarakat yang kurang mengetahui penulisan bentuk baku yang sesuai dengan KBBI.

(17) bakal gw ingat muka temen yang nemenin gw pas lagi susah. (28/09/20)

Pergeseran bahasa bentuk elitis kata temen dalam bentuk baku, yaitu "teman". Penggunaan kata temen merupakan bentuk penulisan yang tidak baku dalam KBBI, sebab ada pelemahan fonem /e/ seharusnya menggunakan fonem /a/ menjadi "teman". Pengguna sosial media lebih cenderung menggunakan tidak baku dengan 
pelemahan fonem karena masyarakat kurang mengetahui bentuk baku menjadi penulisan sehari-hari tanpa memperhatikan penulisan bentuk baku.

(18) berusaha ngelupain semuanya tapi belom bisa juga, masi aja lemah. $(25 / 09 / 20)$

Pergeseran kata belom dalam bentuk baku, yaitu "belum". Penggunaan kata belom dalam KBBI tidak baku dengan pelemahan fonem /o/, dalam bentuk baku menggunakan fonem $/ \mathrm{u} /$. Pergeseran bentuk tidak baku dengan pelemahan fonem karena masyarakat pengguna kata tersebut melemahkan fonem dan sudah menjadi kata yang digunakan sehari-hari.

\section{Singkatan yang menyebabkan Tidak Baku Bentuk Elitis \\ a. Kata Baku Disingkat}

(19) tapi kalian pernah ilfeel sm org krm cara typing nya gak sih? (12/10/20)

Pergeseran bentuk elitis pada data (19) di atas terlihat pada kata "sama" menjadi sm, "orang" menjadi org, kata penghubung "karena" menjadi krn. Pergeseran ini muncul karena sebagian besar masyarakat lebih senang menuliskan kata baku yang disingkat dalam sebuah ragam tulis daripada didasarkan pada tata bahasa baku bahasa Indonesia.

(20) ternyata gue cakep juga ye trs kemaren2 insecure buat apaan anjeng. $(28 / 09 / 20)$

Pergeseran bahasa elitis pada data (20) di atas ditemukan pada kata trs sebagai bentuk akronim (pemendekan kata), pembetulan dalam bentuk utuh, yaitu "terus". Kata "terus" dalam konteks kalimat di atas memiliki makna "lantas". Masyarakat kalangan remaja sebagai pengguna bahasa di akun sosial media cenderung menggunakan bahasa akronim sangat fasih dengan kosa kata baru ataupun singkatan yakni meminimalisir panjang kata.

\section{b. Kata Tidak Baku Disingkat}

(21) tapi kalian pernah ilfeel sm org krn cara typing nya gak sih? $(12 / 10 / 20)$

Kata gak dalam kalimat di atas mengalami pergeseran, kata baku yang seharusnya ditulis "tidak atau tak" menjadi kata tidak baku yang disingkat gak. Kata tersebut dapat digunakan untuk menyatakan pengingkaran, penolakan, penyangkalan, dan sebagainya (KBBI). Kata tidak baku tersebut elitis karena sebagian besar masyarakat lebih memilih menggunakan kata gak daripada kata "tidak".

(22) ternyata gue cakep juga ye trs kemaren2 insecure buat apaan anjeng. $(28 / 09 / 20)$ 
Kata ulang kemaren2 dalam kalimat di atas merupakan kata tidak baku yang disingkat. Pergeseran pertama kata kemaren2 terlihat pada kata tidak baku kemaren yang menggunakan fonem /e/ bukan / $i /$, pembetulan yang sesuai bentuk baku dalam KBBI, yaitu "kemarin". Penggeseran kedua, yaitu pada kata ulang kemaren2 dengan bertanda " 2 " pada kata tersebut. Bentuk kata ulang seharusnya ditulis dengan menggunakan tanda hubung (-). Pembetulan yang sesuai dengan kaidah kebahasaan, yaitu "kemarin-kemarin". Pergeseran dengan penggunaan kata ulang angka 2 tersebut seringkali digunakan masyarakat, baik anak-anak, remaja, dewasa, maupun orang tua dalam ragam tulis media sosial yang dituujukan untuk mempersingkat kata atau agar penulisan lebih cepat.

\section{c. Kata Bahasa Asing Disingkat}

(23) $99 \%$ cewek yang berfikir dewasa lebih menyukai cowo yang ga alay dan jarang post fotonya sendiri. $(11 / 10 / 20)$

Kata post pada data (23) di atas merupakan istilah yang mengacu pada gambar, foto, ataupun video yang diunggah. Kata post sebenarnya berasal dari kata "posting", tetapi kata tersebut mengalami penyingkatan atau kliping pada bagian akhir kata menjadi post (penghilangan imbuhan ing). Dikatakan elitis, karena semakin langka orang mengatakan "unggah", yang mewabah adalah kata post atau posting.

\section{Kata dari Bahasa Asing Bentuk Elitis \\ a. Kata Bahasa Asing}

(24) tapi kalian pernah ilfeel sm org krn cara typing nya gak sih? (12/10/20)

Pada data (24) kata typing merupakan kata berbahasa Inggis, yang memiliki arti "mengetik". Mengetik di sini identik dengan bentuk tulisan. Kata typing dapat disebut elitis karena dalam kalimat di atas penggunaannya dicampur dengan bahasa Indonesia mengalami pergeseran.

(25) males banget denger excuse "aku emang orangnya gini" padahal bisa jadi lebih baik. kamu bukan bonsai, grow up. $(12 / 11 / 20)$

Kasus bahasa elitis dalam bahasa asing pada kalimat ini terlihat dari pemakaian kata berbahasa Inggis excuse dan grow up. Kata excuse dapat berarti alasan, sedangkan kata grow up memiliki makna tumbuhlah Penggunaan kata alasan dan tumbuhlah dirasa sudah biasa. Untuk itu, digunakanlah bahasa Inggris di dalam sebuah percakapan berbahasa Indonesia, agar terlihat kekinian dan tidak tertinggal oleh zaman, tetapi hal demikian mengakibatkan terjadinya pergeseran bahasa.

(26) Mau aku telfon?"

Kalimat sederhana, tapi bisa bikin mood jadi lebih bagus aja gitu. $(12 / 11 / 20)$

Kata mood memiliki arti "suasana hati". Kata tersebut biasanya digunakan anak muda untuk menyatakan suasana hati, termasuk dalam penggunaan kata 
berbahasa Indonesia. Pergeseran bentuk elitis berbahasa asing ini terjadi karena penggunaan kata mood lebih intens daripada penggunaan kata suasana hati.

(27) siapa yang semenjak kelas online makin ga ngerti apa-apa? Aku $(23 / 09 / 20)$

Online dalam bahasa Indonesia istilah online dipadankan menjadi dalam jaringan (daring) terhubung melalui jejaring komputer, internet, dan sebagainnya. Online merupkan pergeseran bahasa elitis yang digunkan masyarakat umum baik anakanak, dewasa, maupun orang tua saat ini mengenal istilah online. Pergeseran bahasa elitis pada istilah online masyarakat mulai mengenal pada masa pembelajaran jarak jauh karena adanya pandemi corona.

(28) ternyata gue cakep juga ye trs kemaren2 insecure buat apaan anjeng. $(28 / 09 / 20)$

Insecure bentuk bahasa asing dengan makna tidak diplesetkan merupakan istilah padanan bahasa inggris dengan bahasa Indonesia yang berarti "tidak aman". Pergeseran bahasa elitis berbahasa asing insecure dapat dikatakan sebagai perasaan yang tidak aman. Anak muda merasa ketidakamanan terjadi saat merasa malu, bersalah, kekurangan, atau tidak mampu. belakangan ini anak muda menyisipkan kata tersebut dalam media sosial dalam bahkan dalam keseharian kalangan anak muda.

(29) aku Selective dalam memilih sendok makan. $(11 / 11 / 20)$

Selective bentuk kata bahasa asing makna tidak diplesetkan merupakan padanan bahasa Inggris dengan bahasa Indonesia yang berarti "pemilih". Pergeseran bahasa elitis pada kata selective sebagai bentuk berbahasa asing untuk pemakaian berbahsa gengsi yang bertujuan terlihat keren dan kekinian. Pelafalan tersebut digunakan remaja masa kini pergeseran antara bahasa Indonesia ke dalam bahasa asing semakin populer. Remaja cenderung lebih suka bahasa asing daripada kata "pemilih" yang ditemukan dalam bahasa tulis di Instagram.

(30) Bisa-bisanya hati gua stuck sama elu doing. (23/09/20)

Stuck bentuk kata bahasa asing makna tidak diplesetkan merupakan padanan bahasa Inggris dengan bahasa Indonesia yang berarti "mentok". Pergeseran bahasa elitis pada kata stuck sebagai bentuk berbahasa asing untuk anak remaja mengenai percintaan sudah mentok dengan dia menggunakan kosa kata baru bahasa asing. Kata stuck dari bahasa asing yang dipakai sebagai bentuk pergaulan dalam media sosial anak remaja masa kini.

\section{b. Frasa Bahasa Asing}

(31) Self Reminder:

Buatlah orang tuamu bangga, musuhmu iri, mantanmu menyesal, dan dirimu bahagia. $(19 / 09 / 20)$ 
Pergeseran bahasa asing berkembang pada zaman saat ini orang mengatakan atau menuliskan frasa bahasa asing bentuk pengingat diri dengan bahasa Inggris, yakni self reminder. Banyak sekali bermunculan kata-kata atau quotes pengingat diri di media sosia. Kata-kata yang ditujukan sebagai pengingat terhadap diri sendiri itupun lebih dikenal dengan self reminder.

(32) "Sudah berjuang, sudah ngerasa dekat..eh sekalinya gak masuk close friend $I G " .(22 / 09 / 20)$

Close friend $I G$ merupakan bentuk frasa bahasa asing dengan istilah padanan bahasa Inggris dengan bahasa Indonesia yang berarti "teman dekat ig". Pergeseran bentuk elitis berbahasa asing tersebut, kaum remaja dalam penggunaan Instagram lebih mengutamakan bahasa asing daripada bahasa Indonesia. Penggunaan fitur close friend membuat daftar teman-teman terdekat. Daftar tersebut sebagai teman-teman yang terpilih untuk bisa melihat story dalam instagram tersebut. Ketika akan mengunggah story dengan pilihan opsi close friend. Teman yang masuk sebgai daftar close friend akan melihat lingkaran hijau.

\section{c. Kalimat Bahasa Asing}

(33) ketiduran karna kecapean is the best kind of slee. (19/09/20)

Is the best kind of sleep merupakan bentuk frasa bahasa asing padanan bahasa Inggris dengan bahasa Indonesia yang berarti "adalah tidur paling enak". Pergeseran bentuk elitis is the best kind of sleep sebagai bentuk kalangan dewasa yang lebih mengedepankan bahasa asing daripada penggunaan "adalah tidur paling enak" dalam ragam tulis di media sosial. Penggunan bahasa tersebut yang digunakan kalangan muda merasakan kelelahan dalam aktivitas sehari-hari.

(34) Kok lo mainnya sama dia lagi sih" oh well honey, tunggu sampai umur kamu di 20-an keatas dan kamu bakalan tau kenapa you keep your small circle. friends with many but trust any. $(28 / 09 / 20)$

Bentuk elitis bahasa asing pada data (34) di atas ditunjukkan melalui kalimat berbahasa Inggis oh well honey (oh baiklah sayang), you keep your small circle (kamu menjaga lingkaran kecilmu), dan friend with many but trust any (berteman dengan banyak orang, tetapi mempercayai siapa saja).

\section{PENUTUP}

Mengamalkan bahasa Indonesia yang baik dan benar tidaklah mudah. Kaum pelajar contohnya, mereka lebih asyik berkomunikasi dengan bahasa yang dianggapnya lebih bergengsi. Misalnya saja penggunaan kata selective (yang harusnya selektif) di tengah kalimat berbahasa Indonesia. Penggunaan bahasa yang elitis dahulunya hanya menyasar kalangan tertentu. Namun kini, sebagian besar masyarakat ikut mengabaikan bahasa yang baik dan benar sesuai dengan Tata Bahasa Baku Bahasa Indonesia. Hal ini berdampak ketika semakin banyak pemangku kepentingan bahasa yang meninggalkan ragam bahasa baku, maka 
bahasa akan semakin elitis. Bahasa yang elitis dapat dilihat dari pembentukan kata baru, baik mengubah kata yang sudah ada sebelumnya atau melakukan inovasi kata baru. Berdasarkan hasil penelitian terhadap pergeseran bahasa pada penggunaan ragam bahasa elitis dalam akun instagram Humor Recehku. Penelitian ini menemukan kata, frasa, maupun kalimat yang elitis. Pertama, penggunaan kata tidak baku, yang meliputi kata tidak baku tanpa plesetan, kata tidak baku dengan plesetan, dan kata tidak baku pelemahan fonem. Kedua, penggunaan singkatan, yang terdiri atas kata baku yang disingkat, kata tidak baku disingkat, dan kata bahasa asing yang disingkat. Ketiga, kata berbahasa asing, meliputi kata, frasa, dan kalimat yang berbahasa asing.

\section{DAFTAR PUSTAKA}

Ariyanti, T. D. (2019). Kesalahan Penulisan Kata tidak Baku pada Merek Dagang Toko dan Jasa di Kota Bengkulu. Pesona: Prosiding Pekan Seminar Nasional Pendidikan Bahasa dan Sastra Indonesia, 1(2), 43-52. https://journal.uhamka.ac.id/index.php/pesona/article/view/3771

Bhakti, W. P. (2020). Pergeseran Penggunaan Bhasa Jawa ke Bahasa Indonesia dalam Komunikasi Keluarga di Sleman. Jurnal Skripta, 6(2), 29-40. https://doi.org/10.31316/skripta.v6i2.811

Diniati, \& Saputro. (2017). Manajemen Kesan Pengguna Media Sosial Instagram dalam Mengeksistensikan Pancasila. Wacana, 16(1), 57-83. https://doi.org/10.32509/wacana.v16i1.12

Djamareng, J., \& Jufriadi. (2016). Pengaruh Sikap dan Peran Orang Tua terhadap Pergeseran Bahasa Luwu di Kalangan Anak-anak pada Masyarakat Luwu Kota Palopo. Palita: Journal of Social-Religi Research, 1(1), 79-95. https://doi.org/10.24256/pal.v1i1.62

Gunawan, F. (2013). Implikasi Penggunaan Bahasa Gaul terhadap Pemakaian Bahasa Indonesia di Kalangan Siswa SMAN 3 Kendari. Al-Izzah, 8(1), 56-72. http://dx.doi.org/10.31332/ai.v8i1.87

Grbich, C. (2007). Qualitative data analysis: An intriduction. London: Sage Publication.

Gustiasari, D. R. (2018). Pengaruh Perkembangan Zaman terhadap Pergeseran Tata Bahasa Indonesia; Studi Kasus pada Pengguna Instagram Tahun 2018. Jurnal Renaissance, 3(02), 433-442. http://www.ejournalacademia.org/index.php/renaissance

Hendrastuti, R. (2015). Variasi Penggunaan Bahasa pada Ruang Publik di Kota Surakarta. Kandai, 11(1), 29-43. https://doi.org/10.26499/jk.v11i1.214

Hilaliyah, H. (2010). Maraknya Penggunaan Bahasa Gaul di Kalangan Pelajar Sekolah Menengah Atas. Deiksis, 02(01), 13-26. http://dx.doi.org/10.30998/deiksis.v2i01.391

Istiqomah, D. S., Istiqomah, D. S., \& Nugraha, V. (2018). Analisis Penggunaan Bahasa Prokem pada Media Sosial. Jurnal Parole: Jurnal Pendidikan Bahasa dan Sastra Indonesia, 1(5), 665-674. http://dx.doi.org/10.22460/p.v1i5p\%25p.966

Jamilah. (2017). Penggunaan Bahasa Baku dalam Karya Ilmiah Mahasiswa. Jurnal Tarbiyah (Jurnal Ilmiah Kependidikan), 6(2), 41-51. http://dx.doi.org/10.18592/tarbiyah.v6i2.1603

Oktavia, W. (2019). Eskalasi Bahasa Indoglish dalam Ruang Publik Media Sosial. Diglosia: Jurnal Kajian Bahasa, Sastra, dan Pengajarannya, 2(2), 83-92. https://doi.org/10.30872/diglosia.v2i2.20

Oktaviani, F. (2014). Hubungan antara Penggunaan Bahasa Gaul dengan 
Keterbukaan Komunikasi di Kalangan Siswa. Jika: Jurnal Ilmu Komunikasi, 1(1), 1-9. https://doi.org/10.31294/kom.v1i1.232.g198

Permatasari, N. E., Khasanah, I. M., \& Putri, N. A. M. (2019). Kesalahan Berbahasa dalam Majalah Pandawa IAIN Surakarta Edisi 2018 pada Tataran Ejaan dan Sintaksis. Diglosia: Jurnal Kajian Bahasa, Sastra, Dan Pengajarannya, 2(2), 103114. https://doi.org/10.30872/diglosia.v2i2.pp93-104

Putri, N. W. (2018). Pergeseran Bahasa Daerah Lampung pada Masyarakat Kota Bandar Lampung. Jurnal Penelitian Humaniora, 19(2), 77-86. https://doi.org/10.23917/humaniora.v19i2.6810

Qory'ah, A. N., Savira, A. T., \& Inderasari, E. (2019). Variasi Bahasa Indoglish dan Idiolek Publik Figur di Instagram. Transformatika: Jurnal Bahasa, Sastra, dan Pengajarannya, 3(2), 136-149. https://doi.org/10.31002/transformatika.v

Rahardi, R. K. (2014). Bahasa 'Indoglish' dan 'Jawanesia' dan Dampaknya bagi Pemartabatan Bahasa Indonesia. Kajian Linguistik dan Sastra, 26(1), 1-21. https://doi.org/10.23917/kls.v26i1.4076

Raihany, A. (2015). Pergeseran Penggunaan Bahasa Madura di Kalangan Anakanak Sekolah Dasar Negeri di Desa Pangarangan Kecamatan Kota Sumenep. Nuansa, 12(1), 47-74. http://ejournal.stainpamekasan.ac.id/index.php/nuansa/article/view/697

Sari, N. W. E., \& Wedasuwari, I. A. M. (2014). Pilihan Bahasa Siswa Kelas XI IPA 2 SMA (SLUA) 1 Saraswati Denpasar. Jumal Bakti Saraswati, 03(02), 40-47. http://jurnal.unmas.ac.id/index.php/Bakti/article/view/67

Setiyanto, E. (2018). Humor dalam Rambu Lalu Lintas. Widyaparwa, 46(2), 99-111. https://doi.org/10.26499/wdprw.v46i2.206

Soedjatmiko. (1984). Etika Pembebasan: Pilihan Karangan tentang: Agama, Kebudayaan, Sejarah, dan Ilmu Pengetahun. Jakarta: LP3ES dan Yayasan Obo.

Sugiyono. (2014). Metode Penelitian Pendidikan Pendekatan Kuantitatif, Kualitatif, dan $R \& D$. Alfabeta.

Supriadin. (2016). Identifikasi Penggunaan Kosakata Baku dalam Wacana Bahasa Indonesia pada Siswa Kelas VII di SMP Negeri 1 Wera Kabupaten Bima Tahun Pelajaran 2013/2014. Jime: Jurnal Ilmiah Mandala Education, 9(2), 150-161. http://dx.doi.org/10.36312/jime.v2i2.91

Sutrisna, D. (2017). Analisis Kesalahan Morfologi Bahasa Indonesia dalam Surat Kabar Radar Majalengka Edisi 16 dan 25 April 2016. Diglosia: Jurnal Pendidikan, Kebahasaan, dan Kesusastraan Indonesia, 1(1), 16-33. http://jurnal.unma.ac.id/index.php/dl/article/view/426

Tutik, A. D., Fitriani, N., \& Inderasari, E. (2020). Variasi dan Fungsi Ragam Bahasa Pada Iklan dan Slogan Situs Belanja Online Shopee. Imajeri: Jumal Pendidikan Bahasa Dan Sastra Indonesia, 02(2), 137-148. https://doi.org/10.22236/imajeri.v2i2.5089

Umar, A. (2007). Stratifikasi Sosial dalam Bahasa Indonesia. Medan Makna, 4, 9297.

Yuniar, Y., Azizah, N., \& Irma, C. N. (2020). Analisis Kesalahan Berbahasa Penulisan Surat Lamaran Pekerjaan Siswa SMk Al-Huda Bumiayu. Diglosia: Jurnal Kajian Bahasa, Sastra, dan Pengajarannya, 3(2), 189-196. https://doi.org/10.30872/diglosia.v3i2.32

Yuwana. (2019). Strategi Penciptaan Materi Humor: Analisis Transitivitas. Leksema, 4(1), 1-10. https://doi.org/10.22515/ljbs.v4i1.1478 
Zaim, M. (2015). Pergeseran Sistem Pembentukan Kata Bahasa Indonesia: Kajian Akronim, Bleding, dan Kliping. Linguistik Indonesia, 33(2), 173-192. https://doi.org/10.26499/li.v33i2.36 